\title{
Selizitapia gen. nov. (Hemiptera: Fulgoromorpha: Flatidae) from tapia woodlands of Madagascar
}

\author{
Dariusz ŚWIERCZEWSKI ${ }^{1, *}$ \& Adam STROIŃSKI ${ }^{2}$ \\ ${ }^{1}$ Faculty of Science and Technology, Jan Długosz University, Al. Armii Krajowej 13/15, \\ 42-201 Częstochowa, Poland. \\ ${ }^{2}$ Museum and Institute of Zoology, Polish Academy of Sciences, Wilcza 64, \\ 00-679 Warszawa, Poland. \\ *Corresponding author: dswier@ujd.edu.pl \\ 2Email: adam@miiz.waw.pl \\ $1 \odot$ https://orcid.org/0000-0001-5589-4388 \\ $2 \odot$ https://orcid.org/0000-0003-0876-9263 \\ ${ }^{1}$ urn:lsid:zoobank.org:author:44B10853-A845-4E4E-8C55-DA90B3A6A0CE \\ ${ }^{2}$ urn:lsid:zoobank.org:author:EB925C2B-94A6-41A7-949E-9CAE10FD5624
}

\begin{abstract}
A new monotypic genus of flatid planthoppers (Hemiptera: Fulgoromorpha: Flatidae), Selizitapia gen. nov., is described for Selizitapia pennyi gen. et sp. nov. (type species) from the island of Madagascar. Habitus, male and female external and internal genital structures of the new species are illustrated and compared with similar taxa. Selizitapia pennyi gen. et sp. nov. is endemic to Madagascar where it is known to date only from one locality in the Central Plateau and is associated with tapia woodland formation.
\end{abstract}

Keywords. Afrotropic, Fulgoroidea, systematics, taxonomy, new species.

Świerczewski D. \& Stroiński A. 2021. Selizitapia gen. nov. (Hemiptera: Fulgoromorpha: Flatidae) from tapia woodlands of Madagascar. European Journal of Taxonomy 750: 124-139. https://doi.org/10.5852/ejt.2021.750.1367

\section{Introduction}

On a global scale, Madagascar represents one of the world's top twelve 'mega diversity' hotspots with high levels of taxonomic endemism and species-rich tropical environments, being recognized as a naturalist's paradise (Myers et al. 2000; Goodman \& Benstead 2005).

Especially the Malagasy entomofauna is extremely rich and many new species are added to the island check-list year by year (e.g., Chłond et al. 2018; Gnezdilov 2019; Kim et al. 2020).

However, despite major conservation efforts, many unique ecosystems are now in a very large extent fragmented and degraded and examples here can be the eastern littoral forest, the western dry deciduous forest and the central highland tapia woody formation, to mention only these three (Ganzhorn et al. 2001). 
The Flatidae Spinola, 1839 are the fourth largest family of the infraorder Fulgoromorpha Evans, 1946, with 296 genera and 1443 species worldwide, respectively representing $12.0 \%$ and $10.5 \%$ of all planthoppers described (Bourgoin 2020). They are the most diverse in all regions of the tropics, far less diverse in the Holarctic (Bartlett et al. 2018) and with a latitudinal profile mostly distributed in the northern hemisphere between $10^{\circ}$ and $45^{\circ}$ of latitude (Bourgoin 2020). The family is divided into two easily distinguishable subfamilies: Flatinae Spinola, 1839 with fore wings, which are held parallel to the body, and Flatoidinae Melichar, 1901 with wings held horizontally (O'Brien 2002). In Madagascar, Flatidae are represented by 21 genera with 52 species of Flatinae and 11 genera with 41 species of Flatoidinae (32 genera and 93 species in total).

Madagascan Selizini Distant, 1906 is represented by five genera and eight species. Species belonging to the genus Urana Melichar, 1902 - U. paradoxa Melichar, 1902 and U. unica Stroiński \& Świerczewski, 2012 - are recorded across north-south mountain ranges and associated with the ecotone vegetation of high altitude-medium altitude moist evergreen forest (Stroiński \& Świerczewski 2012). Peyrierasus philippiae Stroiński \& Świerczewski, 2013 is related to the montane ericoid thicket in the Anosyenne Mountains of the southeast. Both species of the genus Lembakaria Świerczewski \& Stroiński, 2019 L. saintemariae Świerczewski \& Stroiński, 2019 and L. mikeae Świerczewski \& Stroiński, 2019 - can be found in the extreme south and are confined to dry spiny thicket (Świerczewski \& Stroiński 2019a), whereas Kelyflata ilakakae Świerczewski \& Stroiński, 2019 is associated with tapia woodlands and K. capensis Świerczewski \& Stroiński, 2019 with spiny bush of the south (Świerczewski \& Stroiński 2019b). All genera listed above together with Stenocyarda angustata (Melichar, 1902) are endemic to the island.

In this paper, an additional monotypic genus of flatid planthoppers Selizitapia gen. nov., is described for Selizitapia pennyi gen. et sp. nov. (type species), which is associated with, endemic to Madagascar, a vegetation formation known as tapia woodlands.

\section{Material and methods}

\section{Material}

The material studied comes from the collection of the California Academy of Sciences in San Francisco, USA. For more than two decades, Academy entomologists have led research expeditions to the island and their results can be found under the following link: https://www.calacademy.org/learn-explore/scientific-expeditions/madagascar.

Depository of material is abbreviated as follows:

CAS = California Academy of Sciences, Department of Entomology, San Francisco (USA)

MIZ = Museum and Institute of Zoology PAS, Warsaw (Poland)

Label information of all specimens examined is between double quotation marks and provided verbatim with each line separated by a slash (/).

\section{Preparations and illustration}

All specimens were originally preserved in $70 \%$ ethanol, but were subsequently dried and pinned. The abdomens of the examined specimens were removed and cleared for 30 minutes in warm $\left(50^{\circ} \mathrm{C}\right)$ $10 \% \mathrm{KOH}$ solution with a few drops of chlorazol black (CAS No. 1937-37-7) for staining the ectodermic structures based on the method introduced by Carayon (1969) and Bourgoin (1993). Dissections and cleaning of genital structures were performed in distilled water. Final observations and drawings of genital structures were done in glycerol using a camera lucida attached to a light microscope. The 
SEM photographs of dry, uncoated specimens were taken in the Laboratory of Scanning Microscopy, Museum and Institute of Zoology, Polish Academy of Sciences (Warsaw), using a scanning electron microscope HITACHI S-3400N under low vacuum conditions.

Descriptions of the external characters of head, thorax and abdomen were based on SEM photographs, whereas descriptions of male and female terminalia were based on macerated and stained structures.

\section{Measurements and abbreviations}

Measurements were made with an ocular micrometer. The following measurements, ratios and their abbreviations were used in this study:

Total length $=$ length of specimen from anterior margin of head to tegmina apex (in dorsal view)

$\mathrm{A} / \mathrm{B}=$ width of vertex at anterior margin / length of vertex at midline

$\mathrm{C} / \mathrm{E} \quad=$ width of frons at upper margin / length of frons at midline

$\mathrm{D} / \mathrm{E} \quad=$ maximum width of frons / length of frons at midline

$\mathrm{F} / \mathrm{B}=$ length of pronotum at midline / length of vertex at midline

$\mathrm{G} / \mathrm{F} \quad=$ length of mesonotum at midline / length of pronotum at midline

$\mathrm{G} / \mathrm{B}+\mathrm{F}=$ length of mesonotum at midline / cumulative length of vertex and pronotum at midline

$\mathrm{G} / \mathrm{H} \quad=$ length of mesonotum at midline / width of mesonotum between lateral angles

$\mathrm{I} / \mathrm{J}=$ length of tegmen from the base to the apical margin in median portion / width of tegmen measured from the apex of clavus to the anterior margin

$\mathrm{I} / \mathrm{K}=$ length of tegmen from the base to the apical margin in median portion / width of tegmen at the widest part

The metatibiotarsal formula LT-T/Mt1/Mt2 provides the number of spines on the side of the metatibia LT-on the apex of metatibia T, alternatively in two groups of internal Ti and external Te spines separated with a diastema (Ti-Te) / on the apex of first metatarsomere Mt1 / on the apex of second metatarsomere Mt2.

\section{Terminology}

The nomenclature of the forewing (tegmen) veins follows the interpretation proposed by Bourgoin et al. (2015). Antennal structures are named in accordance with Stroiński et al. (2011). The terminology of the genitalia follows Bourgoin (1988) and Bourgoin \& Huang (1990) for the male, and Bourgoin (1993) for the female.

\section{Results}

Class Insecta Linnaeus, 1758

Order Hemiptera Linnaeus, 1758

Suborder Fulgoromorpha Evans, 1946

Superfamily Fulgoroidea Latreille, 1810

Family Flatidae Spinola, 1839

Subfamily Flatinae Spinola, 1839

Tribe Selizini Distant, 1906

Selizitapia gen. nov.

urn:1sid:zoobank.org:act:7CB34782-C76D-43AE-808C-4911F4CB0A2E

Figs 1-7

\section{Type species}

Selizitapia pennyi gen. et sp. nov., here designated. 


\section{Diagnosis}

The new genus differs from other taxa of Selizini in Madagascar by the following characters: 1) wings subrectangular (wings strongly constricted apically in Stenocyarda Fennah, 1965); 2) frons with median carina not diverged (frons with Y-shaped median carina in Urana); 3) mesonotum without gibbosities (mesonotum with four gibbosities in Urana); 4) dorsal part of periandrium unilobate (dorsal part of periandrium bilobate in Lembakaria and trilobate in Kelyflata Świerczewski \& Stroiński, 2019); 5) lateral split of periandrium exceeding $1 / 3$ of its length (lateral split of periandrium reaching $1 / 3$ of its length in Peyrierasus Stroiński \& Świerczewski, 2013).

\section{Etymology}

The generic name is an arbitrary combination of the name of the tribe 'Selizini', which the new genus belongs to, and the name of the forest formation - 'tapia', which the insect is associated with. Gender feminine.

\section{Description}

HEAD. Head with compound eyes, in dorsal view, slightly narrower than thorax. Vertex transverse, constricted in middle, medially slightly overlapped by pronotum: posterior margin carinate and strongly elevated, anterior margin carinate medially, covered by posterior margin, lateral parts obsolete; lateral margins carinate and subparallel (Figs 1A, 2A, C-E). Frons convex, widest at its lower third in frontal view; lateral margins carinate, arcuate and elevated, without incisions; upper margin almost straight; disc of frons with single, well-visible, median carina, laterally with obsolete ridges; frontoclypeal suture arcuate (Figs 1B, 2A-B). Clypeus smooth, weakly convex, without carinae (Figs 1B, 2B). Rostrum with apical segment shorter than subapical one, apex reaching hind coxae level. Compound eyes oval, with narrow callus at posterior margin. Lateral ocelli present. Antennae placed very close to medioventral margin of eyes; scapus small, ring-like, with single setae; pedicel shorter than diameter of eye but distinctly longer than scapus, bulbous, functional area at the top and on dorsal surface with trichoid sensilla type 1 , antennal plate organs present on apical concavity and basally delimiting lateral margins of dorsal functional surface (Figs 2F, 3A).

Thorax. Pronotum, in dorsal view, shorter than mesonotum at midline: anterior margin arcuate with median portion almost straight, reaching anterior margin of compound eyes, posterior margin concave; disc of pronotum wrinkled, without carinae, with lateral impressions and central groove; postocular eminences conical (Figs 1A, 2A, C-E). Mesonotum with scutellum widely deltoid, wider than long at midline, scutellum with elevated apex; disc of mesonotum medially depressed with shallow groove; lateral carinae as ridges, only visible in posterior part and connected with posterior margin (Figs 1A, 2E). Tegmina longer than wide, subrectangular, with distinct venation and numerous transverse veinlets in apical part, without nodal line and with single apical line; costal margin sinuate, costal and sutural angle rounded, apical margin slightly rounded, postclaval sutural margin straight. Costal area short, with dense transverse veinlets, ending at the level of fusion of claval veins (Figs 1C, 3E-F). Costal cell about the same width as costal area, tapering apicad. Basal cell longer than wide. Tegmen with longitudinal veins $\mathrm{ScP}+\mathrm{RA}$ and $\mathrm{RP}$ arising as short common stem from basal cell before bulla. Vein ScP+RA with fork distinctly after RP fork, ending on costal margin with 4 terminals; vein RP with fork before MP fork, ending on costal margin with 8-9 terminals; vein MP with fork distinctly apicad to CuA fork, ending on apical and postclaval margins; $\mathrm{CuA}$ with the first fork distinctly before RP fork. Apical cells subrectangular. Veins of apical half of tegmen wrinkled. Sensory and wax gland-plates concentrated on bulla and costal area, with a few scattered on the whole tegmen (Figs 1C, 3E-F). Clavus ending a bit before the end of costal area; Pcu and $\mathrm{A}_{1}$ joined slightly anterior to clavus apex; $\mathrm{A}_{1}$ slightly elevated; sensory and wax gland-plates concentrated on the area between Pcu and $\mathrm{A}_{1}$ and basal part of the area after $\mathrm{A}_{1}$ vein; single transverse veinlet after Pcu- $\mathrm{A}_{1}$ connection (Figs 1C, 3E). 
Legs. Pro- and mesofemora slightly shorter than tibiae, subrectangular in cross section. Pro- and mesotibiae with shallow groove on external side; apical tarsomere of anterior and median legs longer than cumulative length of second and basal tarsomeres. Metatibiae longer than metafemora, triangular in cross section with two lateral spines and apical row of spines - first lateral spine placed subapically, second lateral spine placed a bit after midlength, apical spines in formula 2 longer (external) +5 shorter (internal); basitarsomere of metatarsus a bit longer than cumulative length of second and apical tarsomeres, with apical spines lined as semicircle -2 external spines a bit longer than 7 shorter internal spines; each internal spine bearing single, distinct seta; second segment of tarsomere with two lateral spines and median pad with setae. Metatibiotarsal formula: $2-(2+5) /(2+7) / 2$ (Figs 3B-D).

Male terminalia. Anal tube, in lateral view, elongate, with breaking point before anal opening, tapering apicad; anal opening placed a bit after midlength; basal part wider than apical part (Figs 4A-B, 5A); in dorsal view, rhomboid, with rounded apex (Figs 4C-D, 5B). Pygofer, in lateral view, with dorsal and ventral margin almost the same length, subparallel; anterior margin weakly concave, posterior margin convex. Genital style triangular, bearing short, hook-like capitulum with apex oriented anteriad (Figs 4A-B, E, 5A).

Phallic complex. Periandrium without any additional processes; in lateral view, about as long as aedeagus; lateral split reaching $2 / 3$ of periandrium (Fig. 5C). Dorsal part of periandrium, in dorsal view, a bit shorter than ventral part, unilobate, smooth, spearhead-shape. Ventral part of periandrium elliptic, tapering apicad, basally with lateral lobes (Fig. 5D). Aedeagus, in lateral view, long and narrow, oriented ventrad, medially with acute process oriented apicad (Fig. 5E); in dorsal view bipartite, symmetrical, with deep median split, reaching $3 / 4$ of its length (Fig. 5F).

Female terminalia. Pregenital sternite with lateral lobes distinctly separated (Figs 6A-B, 7A). Anal tube, in lateral view, covering gonoplac and reaching its posterior margin (Figs 6B, 7C); in dorsal view, elliptic (Figs 6C, 7B). Gonoplac unilobate, rounded posteriorly, oriented ventrad, covering gonapophysis VIII (Figs 6B, 7D); posterior margin with one row of stout teeth, positioned at some distance one from another; teeth of both gonoplacs fitting together in a zip-like manner (Figs 6E-F, 7D). Gonapophysis VIII widely triangular, flattened, slightly oblique in respect to longitudinal body axis (Fig. 7E); endogonocoxal process as long as gonapophysis, wide, tapering apicad, with spiniferous microsculpture. Gonospiculum as in Fig. 7H-I. Bursa copulatrix with single pouch, rounded, cells with weakly sclerotized central areas (Fig. 7F). Spermatheca well developed; ductus receptaculi longer than diverticulum ductus, both parts smooth (Fig. 7G). Tergites of abdomen membranous in median portion (Fig. 6C-D).

\section{Diversity and distribution}

The genus is monotypic and contains a single species from Madagascar.

Selizitapia pennyi gen. et sp. nov.

urn:lsid:zoobank.org:act:FE9BEDC2-9BD1-4E72-8E70-5E91C943E49E

Figs $1-7$

\section{Diagnosis}

The only species in the genus.

\section{Etymology}

The species is dedicated to Dr Norm Penny (1946-2016) - outstanding researcher of Neuropterida, and collection manager at the Department of Entomology at the California Academy of Sciences, San 
Francisco, California. He kindly provided us with invaluable material of Madagascan Flatidae making the previous and current studies possible.

\section{Material examined}

\section{Holotype}

MADAGASCAR: $0^{\Uparrow}$; "MADAGASCAR, Province/ Fianarantsoa, Italaviana, / $35 \mathrm{~km}$ SSE of Antsirabe / 20¹0.40'S, 4705.16'E / 8-24 April 2004"; "California Acad of Sciences / coll: M. Irwin, R. HarinHala / malaise trap - in Uapaca / forest elev 1360 m / MA-24-45"; "CASLOT 044412"; "HOLOTYPE"; "Selizitapia pennyi sp. nov. / Świerczewski \& Stroiński det."; CAS (dry-mounted, abdomen detached, dissected and stored in glycerol in a glass microvial under the specimen).

\section{Paratypes}

All specimens with the locality collection data the same as the holotype apart from the collection codes and the dates of collecting. All dry-mounted, abdomens of some specimens detached, dissected and stored in glycerol in a glass microvial under the specimen.

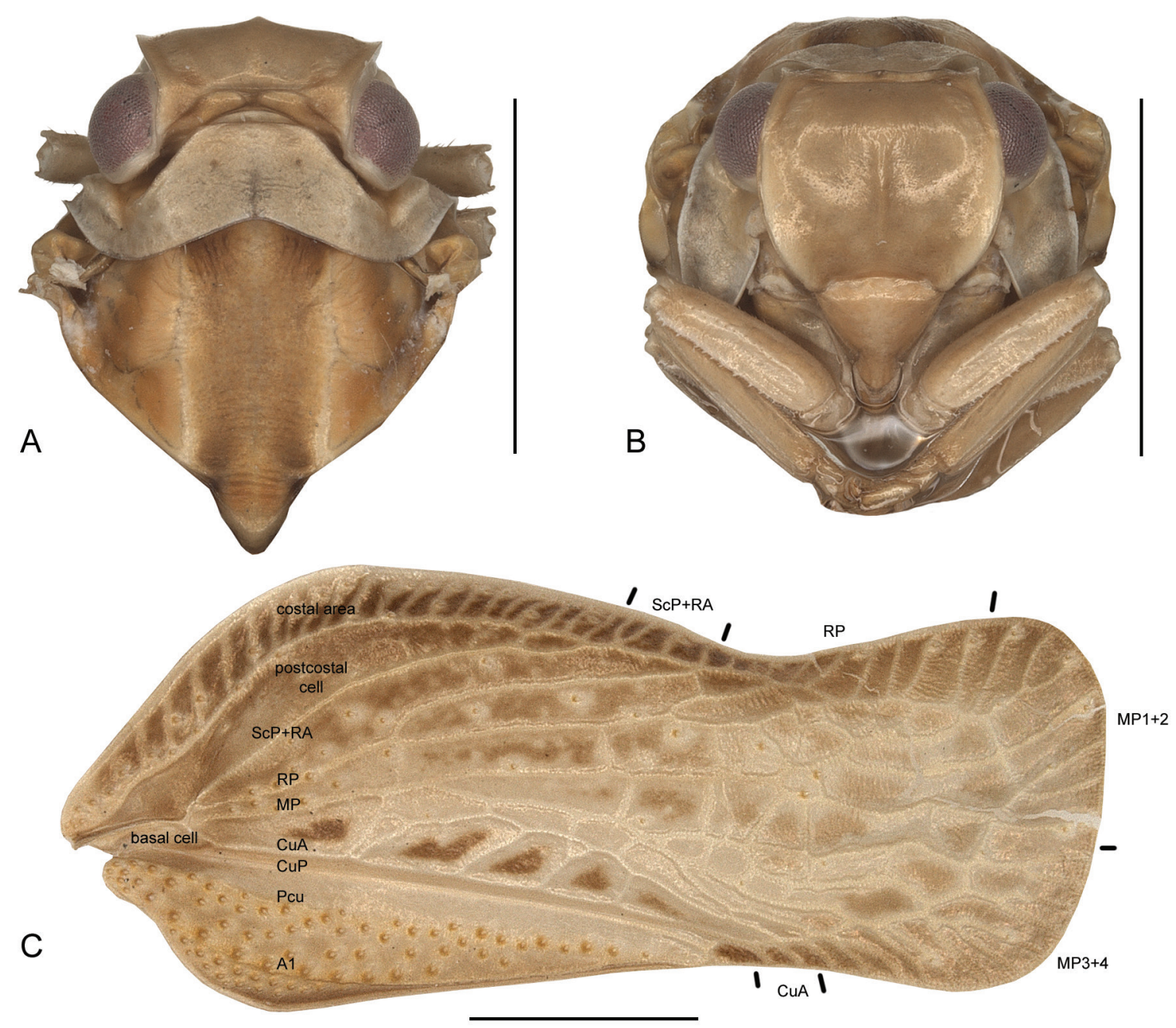

Fig. 1. Selizitapia pennyi gen. et sp. nov. Holotype, $\widehat{\jmath}$ (CAS CASLOT 044412). Habitus. A. Anterior part, dorsal view. B. Same, frontal view. C. Tegmen. Scale bars $=1.0 \mathrm{~mm}$. 
MADAGASCAR - Fianarantsoa Province, Italaviana • 1 क; 9-19 Dec. 2002; MA-24-02; CASLOT

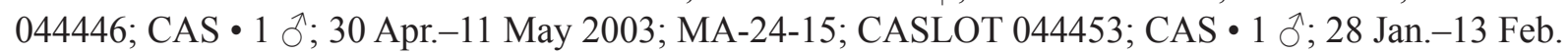
2005; MA-24-57; CASLOT 044465; CAS • 1 क; 28 Jan.-13 Feb. 2005; MA-24-67; CASLOT 044465; CAS • 1 क; 30 Apr.-11 May 2003; MA-24-15, CASLOT 044463; MIZ • 1 \%; 2-14 Oct. 2004; MA-24-
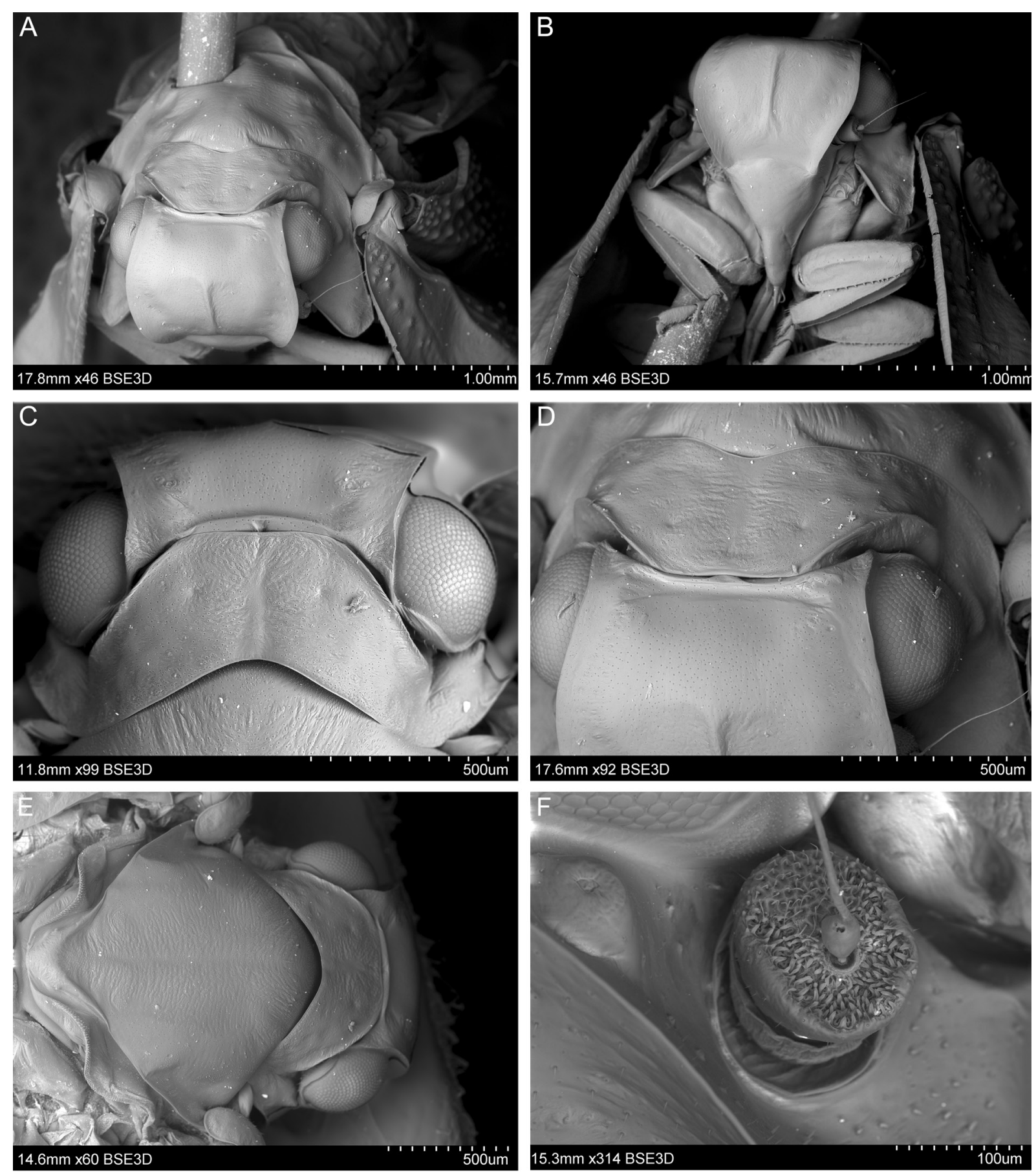

Fig. 2. Selizitapia pennyi gen. et sp. nov. A-B. Paratype, + (CAS CASLOT 044446). C-F. Holotype, $\hat{\sigma}$ (CAS CASLOT 044412). SEM photographs. A. Anterior part of body, fronto-dorsal view. B. Same, frontal view. C. Head and pronotum, dorsal view. D. Upper part of head and pronotum, fronto-dorsal view. E. Head and thorax, dorsal view. F. Antenna, frontal view. 


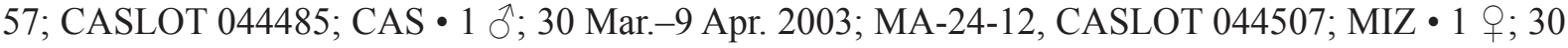
Mar.-9 Apr. 2003; MA-24-12; CASLOT 044507; CAS • 1 क; 10-20 Mar. 2003; MA-24-10; CASLOT 044521; CAS • 1 q; 17-27 Sep. 2003; MA-24-29; CASLOT 044527; CAS • 1 \%; 16-26 Oct. 2003; MA-24-32; CASLOT 044596; CAS.
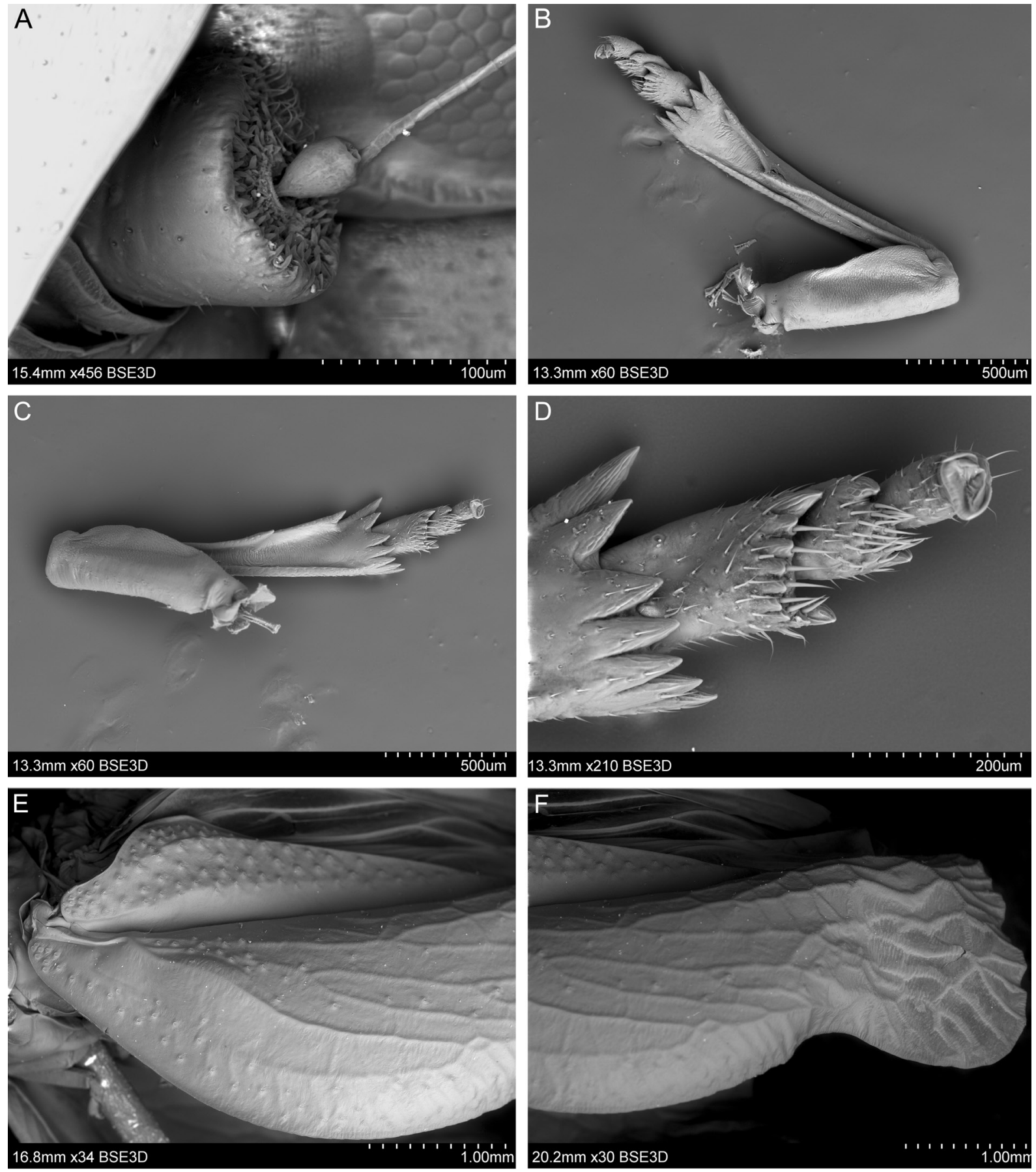

Fig. 3. Selizitapia pennyi gen. et sp. nov. Holotype, ô (CAS CASLOT 044412). SEM photographs. A. Antenna, lateral view. B-C. Hind leg. D. Apical part of metatibia and metatarsus. E. Tegmen, basal part. F. Same, apical part. 


\section{Description}

SizE. Total length $6.8-7.0 \mathrm{~mm}$.

Coloration. Mostly uniformly stramineous with costal area, apical cells and postclaval margin fuscous; dark brown markings between basal part MP and $\mathrm{CuA}$; teeth of gonoplac dark brown (Fig. 1A-C).
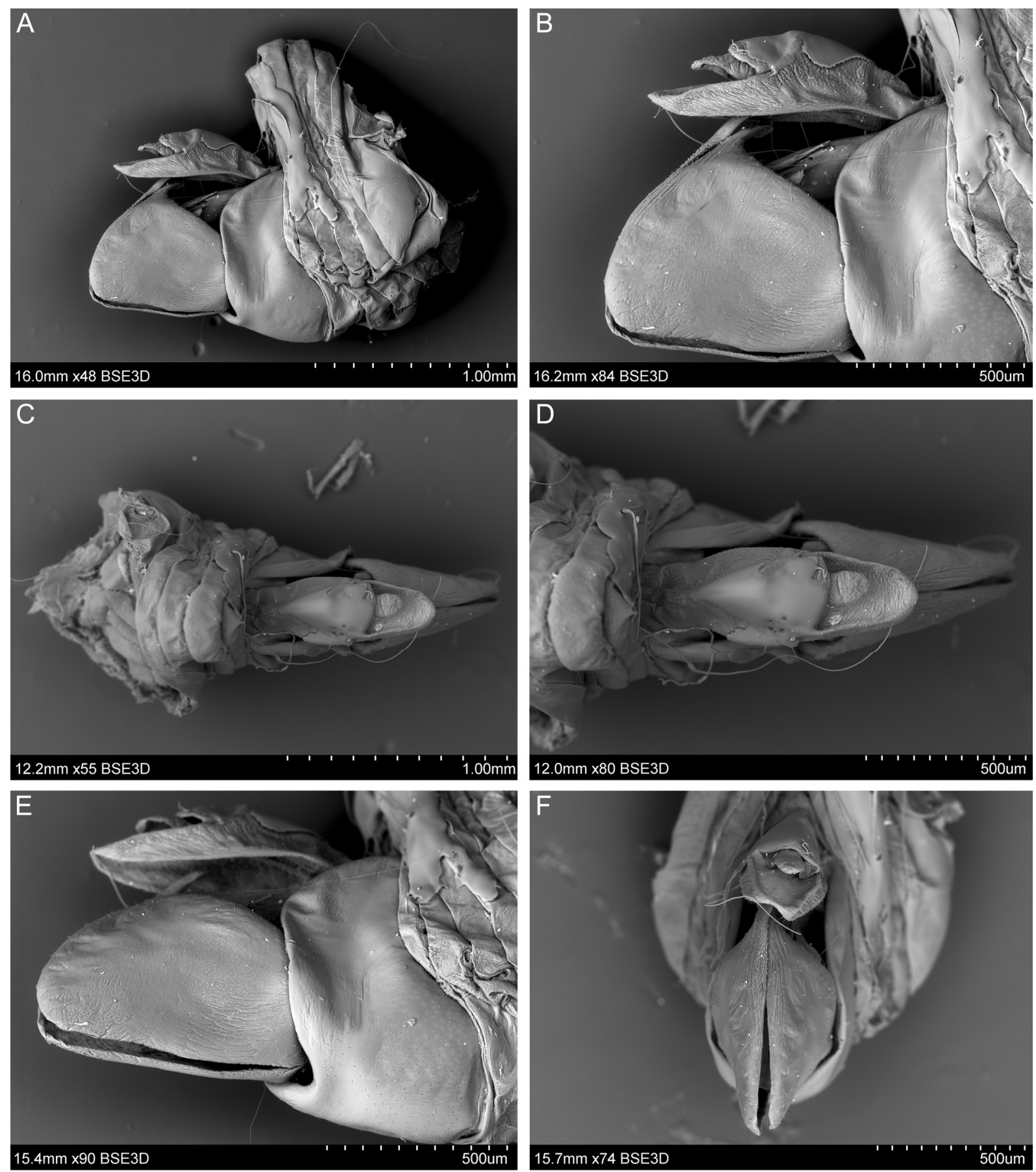

Fig. 4. Selizitapia pennyi gen. et sp. nov. Holotype, $\widehat{O}$ (CAS CASLOT 044412). SEM photographs. A. Abdomen, lateral view. B. Terminalia, lateral view. C. Abdomen, dorsal view. D. Terminalia, dorsal view. E. Terminalia, postero-ventral view. F. Same, fronto-dorsal view. 
Head. Vertex: $\mathrm{A} / \mathrm{B}=16.67$. Frons: $\mathrm{C} / \mathrm{E}=1.00 ; \mathrm{D} / \mathrm{E}=1.20$.

Thorax. Pronotum: $\mathrm{F} / \mathrm{B}=8.33$; mesonotum: $\mathrm{G} / \mathrm{F}=3.20 ; \mathrm{G} / \mathrm{B}+\mathrm{F}=2.86 ; \mathrm{G} / \mathrm{H}=0.89$; tegmen: $\mathrm{I} / \mathrm{J}=3.67$; $\mathrm{I} / \mathrm{K}=2.39$.

Male terminalia. Anal tube, in lateral view, with ventral margin as obtuse angle and dorsal margin arcuate (Fig. 5A). Genital style with posterior margin weakly convex, ventral and dorsal margins almost straight, postero-ventral angle bluntly rounded, not extending to the posterior margin (Fig. 5A). Basal lobes of ventral periandrium small with sinuate margin (Fig. 5D).
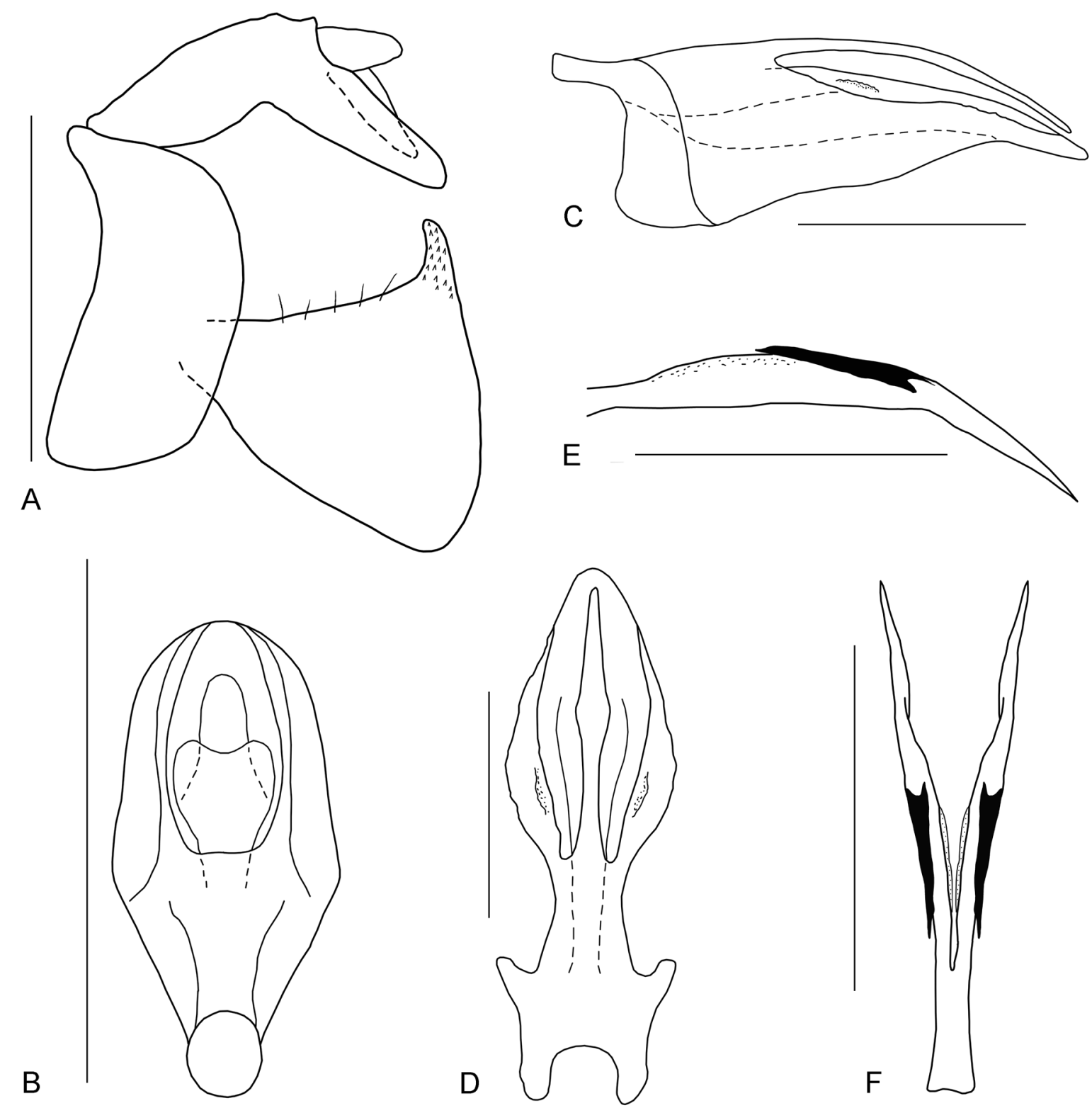

Fig. 5. Selizitapia pennyi gen. et sp. nov. Holotype, $\widehat{\jmath}$ (CAS CASLOT 044412). Line drawings. A. Terminalia, lateral view. B. Anal tube, dorsal view. C. Periandrium, lateral view. D. Same, dorsal view. E. Aedeagus, lateral view. F. Same, dorsal view. Scale bars $=0.5 \mathrm{~mm}$. 
Female terminalia. Pregenital sternite with anterior and posterior margins in median portion almost straight (Fig. 7A). Anal tube with apical margin, in dorsal view, strongly rounded (Fig. 7B); in lateral view, with basal part wider than apical part, anus placed almost at midlength (Fig. 7C). Gonoplacs with membranous part at ventral margin (Fig. 7D). Gonapophysis VIII with subapical 5 massive teeth at dorsal margin (Fig. 7E). Ductus receptaculi and diverticulum ductus widened distally (Fig. 7G).
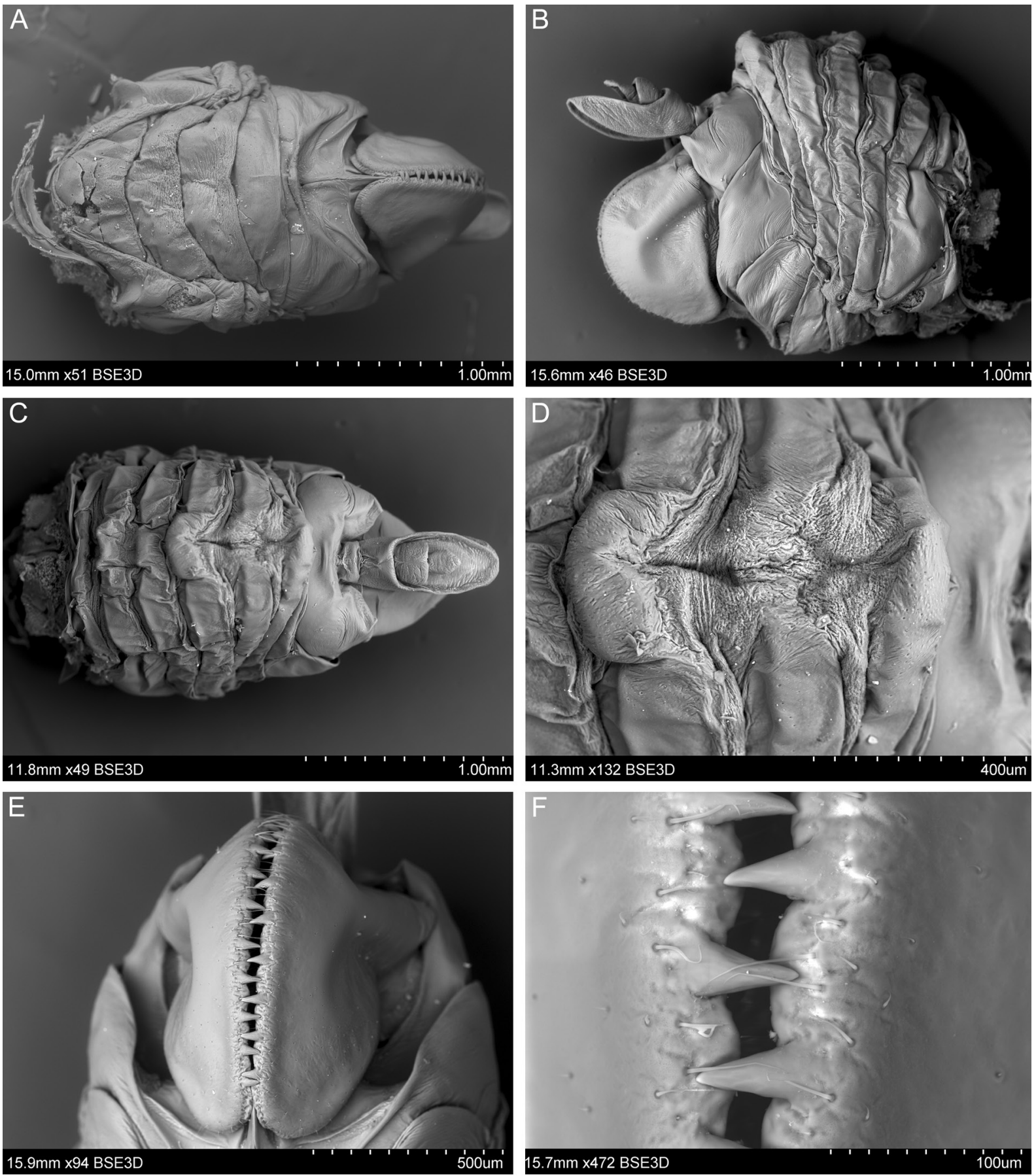

Fig. 6. Selizitapia pennyi gen. et sp. nov. Paratype, $q$ (CAS CASLOT 044463). SEM photographs. A. Abdomen, ventral view. B. Same, lateral view. C. Abdomen, dorsal view. D. Tergites, central membranous part. E. Gonoplacs, fronto-ventral view. F. Gonoplac teeth. 

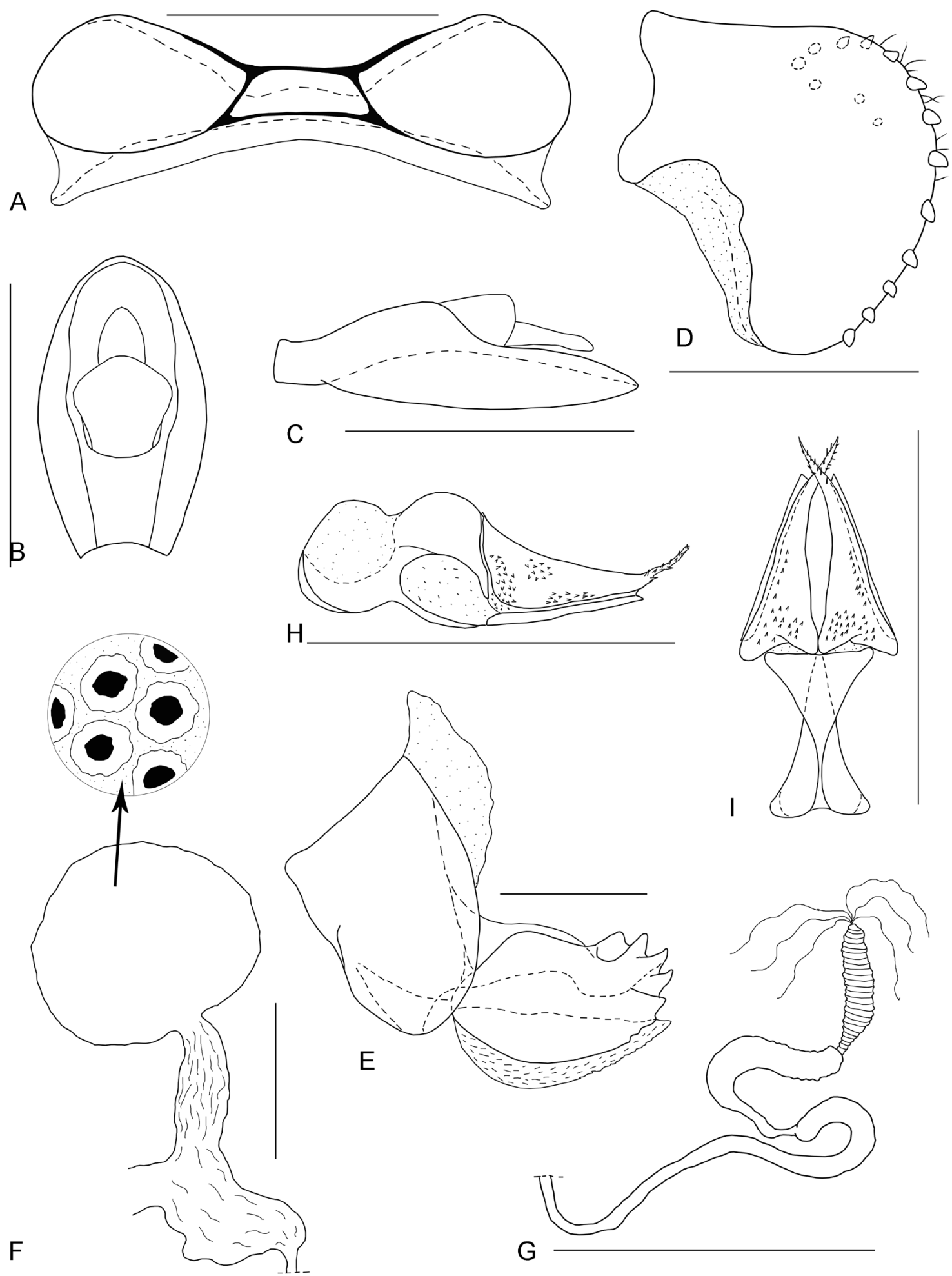

Fig. 7. Selizitapia pennyi gen. et sp. nov. Paratype, $q$ (CAS CASLOT 044463). Line drawings. A. Pregenital sternite, flattened, ventral view. B. Anal tube, dorsal view. C. Same, lateral view. D. Gonoplac, lateral view E. Gonapophysis VIII, lateral view. F. Bursa copulatrix with cells, lateral view. G. Spermatheca. H. Gonapophyses IX and gonospiculum bridge, lateral view. I. Same, dorsal view. Scale bars $=0.5 \mathrm{~mm}$. 


\section{Distribution and habitat}

Madagascar; so far only known from one locality in the central part of the island (35 km SSE of Antsirabe). The type series was collected in a tapia woodland formation, in the season of 2003 from March to May and from September to October.

\section{Discussion}

The biodiversity of Madagascar can be characterised by a high rate of endemism in species and at higher taxonomical levels (Waeber et al. 2019). This may result from a broad ecological diversity occurring in limited areas, with a wide spectrum of unique niches, such as here the tapia woodlands, a humanmodified vegetation formation found in highland zones of central and southwestern Madagascar. It is characterized by two strata: a woody stratum dominated by Uapaca bojeri Baill. (tapia) in association with other woody species of the family Sarcolaenaceae (Madagascar's largest endemic family) and a multi-layer herbaceous stratum represented primarily by species of Asteraceae, Cyperaceae, Lamiaceae, Poaceae, and Rubiaceae (Alvarado et al. 2014a). The latter may harbour many phytophagous taxa including Selizitapia pennyi gen. et sp. nov., together with previously described Phlebopterum tapiae Świerczewski \& Stroiński, 2012 and Kelyflata ilakakae Świerczewski \& Stroiński, 2019. Such a biotope-linked endimicity is also examplified in other groups of insects such as the endemic assassin bug Toxopus italaviana Forthman, Chlond \& Weirauch, 2016 (Heteroptera: Reduviidae) and the ant species Camponotus madagascariensis Forel, 1886 (Hymenoptera: Formicidae) or the endemic earthworm Kynotus blancharti Csuzdi, Razafindrakoto \& Hong, 2017 (Oligochaeta: Lumbricina: Kynotidae) from the area of Antsirabe.

Protection of tapia woodlands equals protection of unique invertebrate communities associated with this formation. The existence of this anthropized vegetation results from the interaction of localised edaphic conditions, human activities and fire. The latter seems to be the most important factor, as was noticed by Alvarado et al. (2014b). The greater frequency and extent of intentionally set bush fires has led to greater diversity among woody and herbaceous native species. Selective exploitation also plays an important role in the conservation of tapia woodland. The economic importance of Uapaca bojeri fruits and of the woody species for wild silk worms should be factored into management planning. However, the most important threat to tapia woodlands is the invasion by exotic plants (Kull 2014).

The high endemism of Madagascan Selizini can be compared to that of Socotra Island where all genera of Selizini described so far seem to be known exclusively from this area. There, we can also observe a unique altitudinal distribution of particular species firmly associated with the different types of vegetation diversified according to the specific terrain relief and changing climatic conditions (Stroiński et al. 2016, 2018; Świerczewski et al. 2017, 2018). However, similarly to Madagascar, all these biotopes are under permanent human-related threats.

In summary, taking into account the enormous loss of the forest cover in Madagascar and the degradation and fragmentation of its habitats, conservation management of these so particular biotopes should be undertaken to allow their protection at all scales, from landscapes to communities and populations. These are crucial to the future survival of herbivorous insect communities composed of highly-specialized species associated with particular native plants and influenced by specific abiotic factors.

\section{Acknowledgements}

We would like to thank two anonymous reviewers for their constructive comments and suggestions, which helped us to improve the manuscript. 


\section{References}

Alvarado S.T., Buisson E., Rabarison H., Rajeriarison C., Birkinshaw C., Lowry P.P. \& Morellato L.P.C. 2014a. Fire and the reproductive phenology of endangered Madagascar sclerophyllous tapia woodlands. South African Journal of Botany 94: 79-87. https://doi.org/10.1016/j.sajb.2014.06.001

Alvarado S.T., Buisson E., Rabarison H., Rajeriarison C., Birkinshaw C. \& Lowry P.P. 2014b. Comparison of plant communities on the Ibity and Itremo massifs, Madagascar, with contrasting conservation histories and current status. Plant Ecology and Diversity 7: 497-508.

https://doi.org/10.1080/17550874.2013.804131

Bartlett C.R., Dietz L.L., Dmitriev D.A., Sanborn A.F., Soulier-Perkins A. \& Wallace M.S. 2018. The diversity of the true hoppers (Hemiptera: Auchenorrhyncha). In: Foottit R.G. \& Adler P.H (eds) Insect Biodiversity: Science and Society. Volume II: 501-590. Wiley Blackwell, Chichester.

https://doi.org/10.1002/9781118945582.ch19

Bourgoin T. 1988. A new interpretation of the homologies of the Hemiptera male genitalia, illustrated by the Tettigometridae (Hemiptera, Fulgoromorpha). In: Vidano C. \& Arzone A. (eds) Proccedings of the $6^{\text {th }}$ Auchenorrhyncha Meeting, Turin, Italy, September 7-11, 1987: 113-120. Consiglio Nazionale delle Ricerche-Special Project IPRA, Turin.

Bourgoin T. 1993. Female genitalia in Hemiptera Fulgoromorpha, morphological and phylogenetic data. Annales de la Société entomologique de France (N.S.) 29: 225-244.

Bourgoin T. 2020. FLOW (Fulgoromorpha Lists On the Web): a world knowledge base dedicated to Fulgoromorpha. Ver. 8, updated 2020-09-17. Available from http://hemiptera-databases.org/flow/ [accessed 28 Sep. 2020].

Bourgoin T. \& Huang J. 1990. Morphologie comparée des genitalia mâles des Trypetimorphini et remarques phylogénétiques (Hemiptera: Fulgoromorpha: Tropiduchidae). Annales de la Société entomologique de France (N.S.) 26: 555-564.

Bourgoin T., Wang R.R., Asche M., Hoch H., Soulier-Perkins A., Stroiński A., Yap S. \& Szwedo J. 2015. From micropterism to hyperpterism: recognition strategy and standardized homology-driven terminology of the forewing venation patterns in planthoppers (Hemiptera: Fulgoromorpha). Zoomorphology 134: 63-77. https://doi.org/10.1007/s00435-014-0243-6

Carayon J. 1969. Emploi du noir chlorazol en anatomie microscopique des insectes. Annales de la Société entomologique de France (N.S.) 5: 179-193.

Chłond D., Guilbert E., Faille A., Ban̆ař P. \& Davranoglou L.R. 2018. A remarkable new species of cavernicolous Collartidini from Madagascar (Hemiptera: Heteroptera: Reduviidae). Zootaxa 4425 (2): 372-384. https://doi.org/10.11646/zootaxa.4425.2.11

Ganzhorn J.U., Lowry II P.P., Schatz G.E. \& Sommer S. 2001. The biodiversity of Madagascar: one of the world's hottest hotspots on its way out. Oryx 35 (4): 346-348.

https://doi.org/10.1046/j.1365-3008.2001.00201.x

Gnezdilov V. 2019. First record of the genus Stenogiffardia (Auchenorrhyncha: Cicadellidae) from Madagascar, with description of a new species and a key to species. Acta Entomologica Musei Nationalis Pragae 59 (2): 549-554. https://doi.org/10.2478/aemnp-2019-0047

Goodman S.M. \& Benstead J.P. 2005. Updated estimates of biotic diversity and endemism for Madagascar. Oryx 39: 1-5. https://doi.org/10.1017/S0030605305000128

Kim J., Roca-Cusachs M., Lim J. \& Jung S. 2020. Malagasycoelum dracula gen. and sp. nov., a new genus and a new species of the subfamily Mirinae (Hemiptera: Heteroptera: Miridae) from Madagascar. Zootaxa 4808 (1): 165-170. https://doi.org/10.11646/zootaxa.4808.1.10 
Kull C.A., Tassin J. \& Carrière S.M. 2014. Approaching invasive species in Madagascar. Madagascar Conservation and Development 9 (2): 60-70. https://doi.org/10.4314/mcd.v9i2.2

Myers N., Mittermeier R.A., Mittermeier C.G., Da Fonseca G.A.B. \& Kent J. 2000. Biodiversity hotspots for conservation priorities. Nature 403: 853-858. https://doi.org/10.1038/35002501

O’Brien L.B. 2002. The wild wonderful world of Fulgoromorpha. Denisia 4: 83-102.

Stroiński A. \& Świerczewski D. 2012. Revision of an extraordinary Selizini genus Urana Melichar, 1902 from Madagascar (Hemiptera: Fulgoromorpha: Flatidae). Journal of Natural History 46 (41-42): 2577-2593. https://doi.org/10.1080/00222933.2012.708457

Stroiński A., Gnezdilov V. \& Bourgoin T. 2011. Sub-brachypterous Ricaniidae (Hemiptera: Fulgoromorpha) of Madagascar with morphological notes for these taxa. Zootaxa 3145 (1): 1-70. https://doi.org/10.11646/zootaxa.3145.1.1

Stroiński A., Malenovský I. \& Świerczewski D. 2016. Two new genera of flatid planthoppers from Socotra island (Hemiptera: Fulgoromorpha: Flatidae). Acta Entomologica Musei Nationalis Pragae 56 (2): 461-489.

Stroiński A., Malenovsky I. \& Świerczewski D. 2018. Socoflata gen. nov., described for two new planthopper species from the mountains in Socotra island (Hemiptera: Fulgoromorpha: Flatidae). Zootaxa 4379 (3): 388-406. https://doi.org/10.11646/zootaxa.4379.3.3

Świerczewski D. \& Stroiński A. 2019a. Lembakaria gen. nov. - a new genus of Selizini from Madagascar spiny forest ecoregion (Hemiptera: Fulgoromoprha: Flatidae). Annales Zoologici 69 (3): 575-588. https://doi.org/10.3161/00034541ANZ2019.69.3.007

Świerczewski D. \& StroińskiA. 2019b. Kelyflata gen. nov. adds to Selizini flatids in Madagascar (Hemiptera: Fulgoromorpha: Flatidae). Zootaxa 4712 (3): 434-444.https://doi.org/10.11646/zootaxa.4712.3.9

Świerczewski D., Malenovský I. \& Stroiński A. 2017. Haloflata gen. nov. - a new genus from salt marshes in Socotra island (Hemiptera: Fulgoromorpha: Flatidae). Annales Zoologici 67 (2): 261-278. https://doi.org/10.3161/00034541ANZ2017.67.2.007

Świerczewski D., Malenovský I. \& Stroiński A. 2018. Medleria gen. nov. adds to the biodiversity of Flatidae (Hemiptera: Fulgoromorpha) in the island of Socotra. European Journal of Taxonomy 422: 1-19. https://doi.org/10.5852/ejt.2018.422

Waeber P.O., Rafanoharana S., Rasamuel H.A. \& Wilmé L. 2019. Parks and reserves in Madagascar: managing biodiversity for a sustainable future. In: Bakar A.N. \& Suratman M.N. (eds) Protected Areas, National Parks and Sustainable Future: 89-108. IntechOpen, London.

https://doi.org/10.5772/intechopen.85348

Manuscript received: 29 September 2020

Manuscript accepted: 3 March 2021

Published on: 20 May 2021

Topic editor: Nesrine Akkari

Section editor: Christopher H. Dietrich

Desk editor: Pepe Fernández

Printed versions of all papers are also deposited in the libraries of the institutes that are members of the EJT consortium: Muséum national d'histoire naturelle, Paris, France; Meise Botanic Garden, Belgium; Royal Museum for Central Africa, Tervuren, Belgium; Royal Belgian Institute of Natural Sciences, 
Brussels, Belgium; Natural History Museum of Denmark, Copenhagen, Denmark; Naturalis Biodiversity Center, Leiden, the Netherlands; Museo Nacional de Ciencias Naturales-CSIC, Madrid, Spain; Real Jardín Botánico de Madrid CSIC, Spain; Zoological Research Museum Alexander Koenig, Bonn, Germany; National Museum, Prague, Czech Republic. 